\title{
Teachers' ICT Skills Scale (TICTS): Reliability and Validity
}

\section{Yalın Kılıç TÜREL, Tuncay Yavuz ÖZDEMiR, Filiz VAROL ${ }^{\mathrm{a}}$}

Fırat Üniversitesi, Eğitim Fakültesi, Elazığ/Turkey

\section{Article Info}

DOI: $10.14812 /$ cuefd. 299864

Keywords:

Information and Communication

Technologies,

in-service teachers,

technology integration

\begin{abstract}
The purpose of this study is to assess the reliability and validity of a scale developed to measure teachers' skills for using information and communication technologies (ICT). The study consisted of three stages. In the first stage, the researchers developed an item pool including 18 items based on a five-point Likert-type style. During the second stage, we collected data from 304 teachers. To demonstrate the reliability and validity of the scale, researchers conducted an exploratory factor analysis using maximum likelihood with oblimin rotation. The factor analysis resulted in a 16-item and threefactor construct that explained $61.5 \%$ of the total variance. The researchers also conduct the parallel analysis to confirm the results of eigen value criterion. In terms of the reliability of the scale, we calculated the Cronbach's alpha values for the overall survey, Factor-1 (3 items), Factor-2 (5 items), and Factor-3 (8 items) as .91, .74, .85, and .89 , respectively. Thus, the instrument is a reliable and valid scale to investigate teachers' ICT skills.
\end{abstract}

\section{Öğretmenlerin Bilgi ve İletişim Teknolojileri Becerileri Ölçeği: Güvenirlik ve Geçerlik}

\section{Makale Bilgisi}

DOI: $10.14812 /$ cuefd.299864

Anahtar Kelimeler

Bilgi ve iletişim teknolojileri, teknoloji entegrasyonu,

öğretmenler

\section{Öz}

Bu çalışmanın amacı öğretmenlerin bilgi ve iletişim teknolojilerini kullanma becerilerini ölçmek amacıyla geliştirilen ölçeğin geçerlik ve güvenirlik çalışmasını yapmaktır. Çalışma üç aşamadan oluşmaktadır. Birinci aşamada, araştırmacılar 5'li Likert tipine uygun 18 maddelik bir madde havuzu oluşturmuştur. İkinci aşamada, 304 öğretmenden veri toplanmıştır. Ölçeğin geçerlik ve güvenirliğini göstermek için açımlayıcı faktör analizi yapılmıştır. Analiz sonucunda 3 faktörlü ve toplamda 16 maddeden oluşan ölçek \%61.5'lik kısmı açıklamıştır. Araştırmacılar sonuçların doğruluğunu kontrol etmek amacı ile paralel analizde yapmıştır. Çalışmanın Cronbach Alpha değeri birinci faktör için ( 3 madde) .91 , ikinci faktör için (5 madde) .74 ve üçüncü faktör için (8 madde) .89 olarak tespit edilmiştir. Analizler, geliştirilen ölçeğin amacı için geçerli ve güvenilir olduğunu göstermektedir.

\section{Introduction}

Recently, there have been substantial developments in the field of information and communication technologies (ICT), which have affected many fields, including educational sciences (Cure \& Ozdener, 2008; Capar \& Vural, 2013). In parallel with the developments in the field of ICT, there seems to have been an increase in social information chunks as well as easy and economical access to information (Ciftci, Taskaya, \& Alemdar, 2013). Thus, it has become more important to truly and effectively use and present information rather than to access information. In addition, all these changes have had an effect on teachers' roles. Today, instead of acknowledging teachers merely as information sources, approaches that regard teachers as models who teach the ways of learning have become more prevalent (Guven, 2001;Yilmaz, 2007; Kogce, Aydin \& Yildiz, 2010; Yorulmaz, Altinkurt, \& Yilmaz, 2015). As a natural 
consequence of these developments, ICT-supported instructional methods have substituted for traditional ones in the transmission of information. In this regard, many countries (Ezziane, 2007; Jhurree, 2005) have shown an effort to update their curricula and to modernize the technical substructures of their schools in order to meet the demands of innovative instructional methods (Aydin, 2000). The main objective in updating the curricula is to educate individuals who think scientifically, question the cause-effect relationships of events, produce information, maintain effective solutions to problems with accurate analysis, use decision-making skills, and have a high level of self-confidence instead of those who memorize information (Yavuz \& Coskun, 2008). Therefore, countries endeavor to support ICT integration into education by restructuring both their curricula and infrastructures (Ezziane, 2007; Jhurree, 2005). As reported by Jonassen and Reeves (1996), technology integration was initially regarded as using computers in instructional environments. However, today it is considered to be a process that positively contributes to students' learning (Belland, 2009; Borokhovski, Bernard, Tamim \& Schmid, 2017; Davies, Dean \& Ball, 2013; Wang \& Woo, 2007).

Adapting ICTs in education is not merely the inclusion of technology-supported instructional materials in instructional settings, but also a multi-dimensional process that requires the consideration of a variety of variables in managerial, instructional, and theoretical domains (Yurdakul, 2011). Tinio (2003) describes effective ICT integration as a process that includes the curriculum, pedagogical approaches, sufficient financial resources, and the readiness level of the organization. Alev and Yigit (2009) maintained that achieving the goals regarding integrating ICT into education depends on learners embracing and internalizing innovations in instructional methods and techniques. Considering teachers' resistance to novelty, teachers who are inexperienced in the use of ICT in their classes might cause delays in the ICT integration into education. Many studies examining ICT integration into instructional settings have revealed problems caused by the lack of teachers' knowledge, skills, and competencies related to such integration (Bingimlas, 2009; Chen, Looi, \& Chen, 2009; Oncu, Delialioglu, \& Brown, 2008). More specifically, Ertmer (1999) focused on various barriers, including personal fears, technical/logistical issues, organizational issues, and pedagogical concerns. Although teachers may not face all of these barriers at once, even one barrier can significantly impede the effective use of ICT in classrooms.

The literature classifies the barriers as first-order, second-order, and third-order barriers. First-order barriers include a lack of time and training as well as institutional support for ICT use; second-order barriers include teachers' pedagogical beliefs and willingness to change (Ertmer, 1999). Tsai and Chai (2012) introduced the third-order barriers, which include teachers' design thinking.

Qualifications of all components in the system, such as teachers' competencies, are related to reaching the determined goals (Yalin, 2001). In contemporary educational systems, schools' and teachers' ICT utilization levels are associated with the realization of their instructional goals (Akin, 2007). However, several studies in this context have demonstrated the existing problems of transferring ICTsupported instructional materials into instructional settings (Akin, 2007; Baki \& Ersoy, 1998; Shiengold, 1995). Similarly, Hawkridge (1983) clarified that practitioners' adaptation and implementation of information technologies are more difficult and time-consuming tasks than other instructional technologies (Ertmer, 2005; Hawkridge, 1983; Selwyn, 2011; Ucuncu, Uzun \& Berkli, 2015). The researchers concluded that teachers' perceptions and attitudes related to ICT skills and competencies are essential for comprehending the integration of ICT in school settings.

With the increase in teachers' use of computers, teachers' attitudes toward computers are being positively changed (Galanouli, Murphy, \& Gardner, 2004). However, Manoucherhri (1999) underscored the lack of teachers' knowledge about ICT and, consequently, the ability to transfer new technologies to learning settings. In other words, teachers need to have sufficient knowledge and skills about ICT as a prerequisite for integrating ICT into learning settings (Manoucherhri, 1999). The European Commission (2010) acknowledged the ICT integration process as a new digital agenda for all European countries. In fact, 28 European countries have defined strategies to provide ICT integration into education and 
started to apply those strategies in 2000.

Within the framework of the EU's adjustment laws, Turkey has accelerated ICT integration into its education process. To support the ICT integration, Turkey initiated several projects, including Education for the Future (Gelecek icin Egitim), Basic Education Project (Temel Egitim Projesi), and FATIH Project. Turkey's Ministry of National Education (MoNE) defined the skills that teachers should have in regard to ICT integration (MoNE, 2006). Those skills are generally about the skills to organize classrooms - physical environment and classroom management - for ICT integration, to make necessary changes in curriculum for ICT integration, to use ICT for professional purposes and so on.

In a similar vein, the International Society for Technology in Education (ISTE) defined teachers' ICT skills as follows:

- Facilitate and inspire student learning and creativity

- Design and develop digital age learning experiences and assessments

- Model digital age work and learning

- $\quad$ Promote and model digital citizenship and responsibility

- $\quad$ Engage in professional growth and leadership(ISTE, 2008)

Critical developments have recently and consistently emerged in ICT, and these changes have also affected the educational settings at a great pace. Today, people discuss the integration of Internetbased applications - such as social networks, file-sharing tools, and video-sharing websites-into education. At this point, it seems beneficial and necessary to develop a scale in order to determine teachers' ICT skills and competencies. In addition to identifying teachers' fundamental ICT skills, it is essential to determine the level of teachers' skills on contemporary web-based applications. In the literature, researchers found only one Turkish scale that was designed based on ISTE's new technology standards. It was designed and validated by Simsek and Yazar (2016). The researchers worked with teacher candidates as well as teachersto develop the scale. Also, another scale was developed by Akbulut, Kesim and Odabasi. They worked with only teacher candidates. However, the current study aimed to design a reliable and valid scale that was consisted of items developed by ICT teacher candidates and data for reliability and validity was collected from in-service teachers. Although ISTE standards are universal, there needs to be a scale that is designed based on in-service teachers' current technology use and knowledge level. To this end, we worked with pre-service teachers to benefit from their views and with in-service teachers knowledge and needs. As a result, we designed a scale that can be used in Turkey.

\section{The Study}

\section{Stage 1: Development of item pool}

Before we started the study, the necessary permissions were gathered from the university and the Ministry of Education in order to conduct the study. As a starting point, all seniors in the university's Department of Computer Education and Instructional Technologies (CEIT) were informed about the study and asked about their willingness to participate. Among 48 teacher candidates, only 20 agreed to participate. During the first stage, teacher candidates generated a list of items in response to the following prompt: __ is an ICT skill that a teacher should have. It took participants approximately 20 to 30 minutes to complete the task, and they ultimately provided an average of 12 items. We did not use ISTE standards to come up with the original items; the reason is that those teacher candidates already knew the ISTE standards as well as what Turkish teachers need in terms of ICT due to their major. After conducting a research review related to teachers' ICT skills (i.e., Altun, 2012; Kutluca, Arslan, \& Ozpinar, 2010; Korkmaz \& Demir, 2012), ICT skills identified in the literature were compared with those that the teacher candidates listed in order to maximize the representativeness of the initial items. As a last step in the first stage, the final draft of the skills was checked by three information technologies teachers, one teacher serving in a middle school, one teacher serving in an elementary school, and a Turkish 
language expert. The final lists included 18 items and were restructured to be a five-point Likert-type questionnaire. According to Dawes (2008), none of the 5-, 7-, and 10-point scales were less desirable than the others in terms of analysis purposes. Thus, the scale for this study ranged from strongly disagree (1 point) to strongly agree (5 points). In addition, there was no negative item in the scale.

\section{Stage 2: Data Collection}

\section{Participants}

In order to reach a high number of participants, professional development seminar timelines were obtained from the Ministry of Education. Depending on the seminar topic, teachers working in elementary and middle public schools located in the city center were required to attend. At the end of the 2012-2013 school year, the Ministry of Education organized a professional development session for 357 teachers; only 346 teachers attended. Participants were informed about the study and signed the consent form to indicate their voluntary participation. Researchers collected data during this session. As 42 teachers did not fully complete the questionnaire, they were dropped from the analysis, leaving 304 participants (199 males and 105 females).

Table 1.

Demographic Characteristics of the Participants

\begin{tabular}{|c|c|c|c|}
\hline & & $f$ & $\%$ \\
\hline \multirow{2}{*}{ 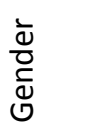 } & Female & 105 & 34.5 \\
\hline & Male & 199 & 65.5 \\
\hline \multirow{6}{*}{ 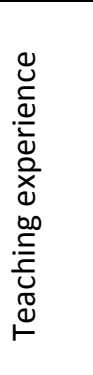 } & Less than 2 years & 36 & 11.84 \\
\hline & $2-5$ years & 55 & 18.09 \\
\hline & $6-10$ years & 62 & 20.39 \\
\hline & $11-15$ years & 82 & 26.97 \\
\hline & $16-20$ years & 16 & 5.26 \\
\hline & More than 21 years & 53 & 17.43 \\
\hline \multirow{3}{*}{ 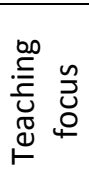 } & Elementary school teacher & 120 & 39.47 \\
\hline & Mathematics teacher & 98 & 32.24 \\
\hline & Science teacher & 86 & 28.29 \\
\hline
\end{tabular}

\section{Procedure}

The researchers introduced the study to the participants and asked for their permission. None of the teachers refused to participate. The printed form of questionnaire was provided to them. The first section of the questionnaire included demographic questions related to teachers' gender, school type, teaching experience, education level, and ownership of a computer with Internet access. The following section aimed to obtain data about teachers' ICT skills. Participants responded to the items on a 5-point scale ranging from completely disagree to completely agree. It took them approximately 10 to 15 minutes to complete the questionnaire.

\section{Data analysis}

In terms of the face and content validity of the scale, items were reviewed by four experts from various fields (two teachers, one from language, and two instructional technologists). After making the 
necessary changes according to the experts' opinions, several procedures were followed, including item analyses, calculation of correlation coefficients, and factor analyses suggested by Gerbing and Anderson (1988). When conducting an item analysis, it is important to check an item's relevance with other items and with the entire scale, which is called item-total correlations. Thompson (2004) suggested .20 as a cut-off criterion while Buyukozturk (2007) recommended a value of .30. Thus, values under the .30 cutoff criterion were excluded from the scale.

Furthermore, in order to be sure about the convenience of data for the factor analysis, the results of Barlett and Kaiser-Meyer-Olkin (KMO) tests were examined. In addition, an exploratory factor analysis (EFA) using the maximum likelihood (ML) method was conducted. Although there is a misunderstanding that Principal Component Analysis (PCA) is a type of EFA (Henson \& Roberts, 2006; Joliffe \& Morgan, 1992; Suhr, 2006), de Winter and Dodou (2012) stressed that there are two most popular types of EFA: "Maximum Likelihood (ML)" and Principal Axis Factoring (PAF). According to Cudeck and O'Dell (1994), when data are normally distributed, ML method is regarded as the best choice for EFA since it gives researcher an opportunity to test statistical significance of factor loadings and calculate the confidence intervals. Thus, after conducting the Maximum Likelihood method with direct oblimin rotation, Cronbach's Alpha coefficients were found for each factor based on EFA and for the entire scale. A splithalf method was also used to reveal the reliability of the scale. The results of these analyses are presented in detail in the next section.

\section{Stage 3: Scale Development}

\section{Descriptive statistics}

For each item in the scale, the descriptive statistics were examined in order to be able to clearly explain the results. Means and standard deviations of each item are presented in Table 2.

Table 2.

Descriptive statistics.

\begin{tabular}{lccc}
\hline Items & $\mathrm{N}$ & Mean & $\mathrm{SD}$ \\
\hline Item-1 & 304 & 3.61 & 1.33 \\
Item-2 & 304 & 3.23 & 1.36 \\
Item-3 & 304 & 3.63 & 1.28 \\
Item-4 & 304 & 3.45 & 1.19 \\
Item-5 & 304 & 3.60 & 1.24 \\
Item-6 & 304 & 3.28 & 1.29 \\
Item-7 & 304 & 3.40 & 1.26 \\
Item-8 & 304 & 3.75 & 1.13 \\
Item-9 & 304 & 3.72 & 1.16 \\
Item-10 & 304 & 3.82 & 1.07 \\
Item-11 & 304 & 3.66 & 1.17 \\
Item-12 & 304 & 3.31 & 1.26 \\
Item-13 & 304 & 3.39 & 1.24 \\
Item-14 & 304 & 3.35 & 1.25 \\
Item-15 & 304 & 3.48 & 1.24 \\
Item-16 & 304 & 2.95 & 1.37 \\
Item-17 & 304 & 3.07 & 1.35 \\
Item-18 & 304 & 3.57 & 1.28 \\
\hline
\end{tabular}

As seen in Table2, the means of almost all items are between the "Neither Agree nor Disagree" and "Agree" intervals. In addition, Item-16, "I can perform the settings of Network, Modem, and Internet by myself," had the lowest mean $(X=2.95)$ while Item-10, "I use presentations (PowerPoint) when delivering instruction in class" had the highest mean score $(X=3.82)$. 


\section{Item Analysis}

In this part of the analyses, the item-total correlations were examined based on the cut-off criterion (.30) as suggested by Buyukozturk (2007). The item-total correlations for each item ranged between .44 and .68; therefore, no item was excluded from the scale due to its correlation level.

\section{Exploratory factor analysis}

In order to provide the structural validity of the scale and to uncover hidden dimensions in it, EFA was employed. Sample size is an important indicator when initiating EFA procedures. Hair, Anderson, Tatham, and Black (1995) suggested a minimum of 5 to 10 cases per variable. In this study, the ratio of cases and variables was approximately 17 (18 items and 304 participants), which represents an adequate sample size for EFA. Before conducting EFA, the KMO measure of sampling adequacy and Barlett's test of sphericity were also analyzed. As Tabachnick and Fidell (2001) suggested, Barlett's test should be significant, and the KMO value is expected to be over .60 to conduct EFA. In addition, a KMO value of .90 and over is regarded as the perfect level. In this study, a significant value of Barlett's test of sphericity, $2897.083(p=.000)$, was obtained; the KMO value was calculated as 0.904 , which suggested good indicators for EFA. Finally, the skewness, kurtosis, and P-P graphics of the data were examined to provide the normality assumption required for the maximum likelihood (ML) method of EFA.

After addressing these assumptions, ML with direct oblimin rotation for EFA was applied. The EFA results were examined based on the criteria (cut-off limit $=.30$ and eigenvalue $>1$ ) recommended by Buyukozturk (2007). The first results revealed three factors whose Eigenvalues were greater than 1 ; the lowest factor loadings were .38. At this level, the acquired three-factor structure explained $60.73 \%$ of the total variance. Eigenvalues and variances for each factor are presented in Table 3.

Table 3.

Eigenvalues and variances for each factor based on the first EFA result.

\begin{tabular}{cccc}
\hline Factor & Eigenvalues & Variances (\%) & Total Variances (\%) \\
1 & 7.598 & 42.213 & 42.213 \\
2 & 1.997 & 11.097 & 53.309 \\
3 & 1.335 & 7.415 & 60.725 \\
\hline
\end{tabular}

Since the "eigenvalue greater than one" criterion to determine the number of factors extracted from data has been criticized for over-extracting factors than warranted, alternative methods such as parallel analysis (PA) have been proposed by Horn (1965). Hayton, Allen, and Scarpello (2004) asserted that parallel analysis is the one of the most reliable factor extraction methods. Thus, the researchers also conduct the parallel analysis to confirm the results of eigenvalue criterion. The researchers determined the 1000 repetitions based on Monte Carlo system as recommended by Lautenschlager (1989). The intersection of the PA and EFA eigenvalues gives us how many factors retained based on the parallel analysis. As seen in Figure 1, the PA dashed line crosses the EFA line right at three factors. 
Figure 1.

Parallel analysis graph

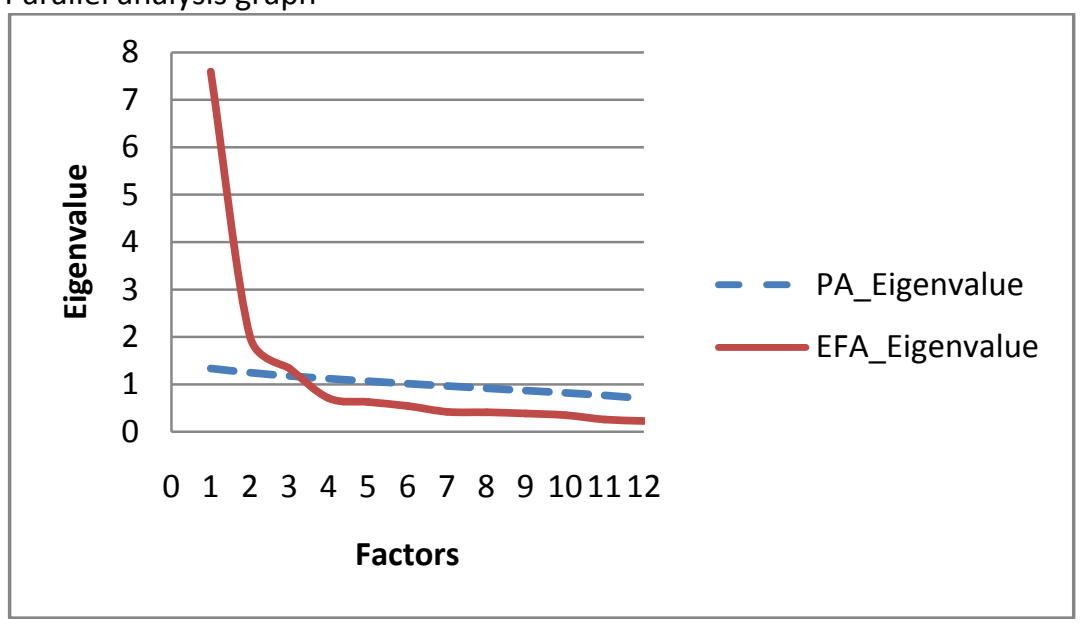

In general, EFA procedures were performed continuously and iteratively by excluding the items from the scale until the expected results were achieved. A three-factor structure was found as a result of the first analysis and identified a coherency within each factor in terms of their items. However, by getting experts' approval, two items in the factor "Use of ICT for Teaching" were not appropriate for the context of the scale as well as their factor. The first item was Item-14, "I can install an operating system (i.e., Windows XP, Windows 7, Linux) on my personal computer." The installation of an operating system is not a pressing need for teachers as computers already come with installed operating systems or an IT person generally takes responsibility for such work. The second item that was excluded from the scale was Item-16, "I can perform the settings of Network, Modem, and Internet by myself." Although the context of this item was related to the first factor, called "Basic Hardware Operations," it was dropped in the third factor, "Use of ICT for Teaching." Items in the first factor also included Item-1, "I can troubleshoot basic technical problems in my computer," and Item-2, "When I buy new computer hardware or device, I can install it into my computer by myself." An overlap was found between these two items and Item-16 in terms of their context. Thus, it was concluded that these two items in the first factor could be substituted for Item-16. Furthermore, by excluding Item-16 from the scale, a more concise structure for the third factor was achieved. In the end, a 16-item scale with three factors was obtained. This three-factor solution explained $61.45 \%$ of the total variance, as seen in Table 4.

Table 4.

Eigenvalues and variances for each factor based on the final EFA result.

\begin{tabular}{cccc}
\hline Factor* & Eigenvalues & Variances (\%) & Total Variances (\%) \\
\hline 3 (8 items) & 6.786 & 42.415 & 42.415 \\
2 (5 items) & 1.722 & 10.760 & 53.175 \\
1 (3 items) & 1.324 & 8.276 & 61.451 \\
\hline
\end{tabular}

Based on the EFA results, three factors were identified. The first factor is the "Basic Hardware Operations" factor; its Cronbach's alpha value was calculated as 0.74 . The second factor is related to ICT knowledge and skills; thus, it was named the "Personal ICT Usage" factor. Example items of this factor included "I can resolve issues with Office software (Microsoft Office, Open Office, etc.) without assistance" (Item-4) and "I can design a simple website" (Item-6). The Cronbach's alpha value was calculated as 0.85 . The last factor was called "Use of ICT for Teaching." It included eight items, all related to ICT skills for instructional purposes. Its Cronbach's alpha value was 0.89 . Table 5 summarizes the correlations among the factors, which were at a medium level. The highest correlation was found between Factors 1 and $2(r=.55)$, and the lowest correlation was between Factors 1 and $3(r=.42)$. 
Table 5.

Factor Correlation Matrix.

\begin{tabular}{lccc}
\hline Factors & Factor1 & Factor 2 & Factor 3 \\
\hline Factor 1. Basic Hardware Operations & 1.000 & & \\
Factor 2. Personal ICT Usage & .545 & 1.000 & \\
Factor 3. Use of ICT for Teaching & .422 & .458 & 1.000 \\
\hline
\end{tabular}

Researchers also showed the evidence of convergent and discriminant validity to determine the convergence between similar constructs and discriminate dissimilar construct, which are calculated based on average variance extracted (AVE). As a result of EFA, factors and items with their factor loadings, Cronbach Alpha and Average Variance Extracted (AVE) coefficients for each factor were presented in Table 6.

Table 6.

Factors, items, and factor loadings for each item.

\begin{tabular}{|c|c|c|}
\hline Item & & $\begin{array}{l}\text { Factor } \\
\text { Loading }\end{array}$ \\
\hline \multicolumn{3}{|c|}{ Factor 1. Basic Hardware Operations (Cronbach Alpha = 0.74) } \\
\hline Item 1 & I can solve simple technical issues on my computer & .801 \\
\hline Item 2 & $\begin{array}{l}\text { When I buy a new computer hardware or device, I can install it into my computer } \\
\text { by myself. }\end{array}$ & .721 \\
\hline Item 3 & My typing skills are good. & .379 \\
\hline \multicolumn{3}{|c|}{ Factor 2. Personal ICT Usage(Cronbach Alpha $=0.85)$} \\
\hline Item 4 & $\begin{array}{l}\text { I can resolve issues with Office software (Microsoft Office, Open Office etc.) } \\
\text { without assistance }\end{array}$ & .835 \\
\hline Item 5 & $\begin{array}{l}\text { I use online instructional materials to figure out how to use software that I wish to } \\
\text { learn. }\end{array}$ & .781 \\
\hline Item 6 & I can design a simple web page. & .695 \\
\hline Item 7 & I can assist somebody planning to buy a new computer as a technical expert. & .626 \\
\hline Item 8 & I can perform basic picture/graphic editing. & .505 \\
\hline \multicolumn{3}{|c|}{ Factor 3. Use of ICT for Teaching (Cronbach Alpha = 0.89) } \\
\hline Item 9 & I can find animations related to my course and deploy them. & .431 \\
\hline Item 10 & I can use presentations (PowerPoint) when delivering instruction in class. & .550 \\
\hline Item 11 & $\begin{array}{l}\text { I can find videos from Internet to support course content and have my students } \\
\text { watch them. }\end{array}$ & .601 \\
\hline Item 12 & I can create online personal BLOGs (i.e., blogger and wordpress). & .701 \\
\hline Item 13 & I can inform my students about computer ethics. & .864 \\
\hline Item 14 & I can effectively use search engines. & .825 \\
\hline Item 15 & $\begin{array}{l}\text { I can use social networking services (i.e., Facebook, Twitter) for educational } \\
\text { purposes. }\end{array}$ & .705 \\
\hline Item 16 & $\begin{array}{l}\text { I can share instructional materials that I find online (via e-mail, Dropbox, Google } \\
\text { Drive, etc.) with my students }\end{array}$ & .484 \\
\hline
\end{tabular}

According to Fornell and Larcker (1981), AVE as a measure of convergent validity should be above .5 and Ping (2009) suggest that the AVE near .5 (by 5-10\%) could be regarded as acceptable. Discriminant validity is analyzed based on the square of AVE (Fornell \& Larcker, 1981) and the coefficients were calculated as $0.44,0.49$, and 0.44 for each factor, respectively. Those values can be regarded as the 
sufficient evidence of the construct validity of the scale.

\section{Reliability}

The overall Cronbach's alpha value for the scale was found to be 0.91 , which can be considered good reliability. Moreover, upon examining the split-half reliability, the reliability values were found to be 0.857 (part 1) and 0.903 (part 2). In the split-half approach using the Spearman-Brown formula, the reliability estimate for the entire questionnaire was 0.753 . Thus, based on these reliability scores, the questionnaire's reliability can be considered high.

\section{Discussion and Conclusion}

The investigation of teachers' ICT skills is critical for researchers. Although many studies have been conducted in this context (e.g., Harris; 1999; Smith \& Kelley, 2007; Twining, 2001; 2002a; 2002b), they are neither well-rounded nor do they include contemporary discussions. When examined carefully, with the increase of ICT usage in education, some studies have investigated teachers' readiness in terms of teaching with ICT and their self-efficacy for ICT (i.e., Hakkaraine et. al., 2000; Kalayci, \& Humiston, 2015; Korkmaz \& Demir, 2012; Koul \& Rubba, 1999; Tchanne-Moran, Woolfolk-Hoy, \& Hoy, 1998; Yilmaz, Yilmaz, \& Turk, 2010). For instance, Korkmaz and Demir (2012) examined teachers' self-efficacy and attitudes toward ICT. Their results revealed that teachers' attitudes and perceptions toward ICT were low. They also found that, although there is no gender effect on their self-efficacy, there is a positive relationship between teaching experience and self-efficacy and attitudes toward ICT.

Teachers' limited computer skills, limited hardware in workplaces, and insufficient technical support are considered to be the main barriers for ICT integration in learning environments (Jenson, Lewis, \& Smith, 2002). From this perspective, teachers' ICT proficiency becomes critical. Specifically, in Turkey, after the start-up of the FATIH Project, teachers' ICT skills were taken into account more. Similarly, researchers (i.e., Early Adopters of Technology, 1999; Gokdas, 2003, Watson, 2001; Yuzgec, 2003) have focused on the necessary technical support that teachers need as well as hardware and educational software support and the ways to fill the identified leaks. Moore and colleagues (1999) identified four categories related to instructional technology skills, one of which was use of technology for educational purposes to enhance instruction. Other studies focusing on the integration of ICT into education have pointed out the value of using ICT for educational purposes (see Bingimlas, 2009; Chen, Looi, \& Chen, 2009; Hakkarainen et al., 2000). These three important aspects were represented as factors in the instrument we developed.

As technology progresses very fast, this study provides important information for researchers, teachers, administrators, and policy-makers who focus on ICT in education. The instrument developed in this study was checked in terms of its reliability and validity. In addition, by using this user-friendly instrument, teachers' ICT skills can be easily evaluated based on the three factors. Akbulut et al. (2007) identified ten factors in their scale including infrastructure, health, ethics, special needs and the others. Also, there are other scales developed for different cultures (i.e. Hernández-Ramos et al. (2014) andHsu (2010)) with various factors, For future research, new questions could be added to the scale to address, for instance, ISTE standards and their reflection on teachers in Turkey.

Similar to other studies, this study faced several limitations. In order to recruit participants, simple random sampling was used. More specifically, participants were selected without taking their major into account. Future research is needed to replicate this study with teachers from the same major so that more specific information about teachers' ICT skills from different majors can be obtained. Although the number of participants for factor analysis was sufficient, conducting a confirmatory factor analysis with the same data set would not be preferable (Kline, 2011; Shieh, \& Demirkol, 2014; van Prooijen \& van der Kloot, 2001). Thus, a confirmatory factor analysis is suggested whilereplicating the study. 


\section{References}

Akbulut, Y., Kesim, M., \& Odabasi, F. (2007). Construct validation of ICT indicators measurement scale (ICTIMS). International Journal of Education and Development using ICT, 3(3).

Akin, M., (2007). Effects of using computer and internet technologies in creating applied subject matter [Bilgisayar ve internet teknolojilerinden yararlanmanin uygulama alan bilgisi olusturma yonunde etkisi (Erzincan Egitim Fakultesi ornegi)], Journal of Erzincan Education Faculty, 9(2), 49-70.

Alev, N. \& Yigit N. (2009). Lecturers' stages of concern and stages of adoption of Information and communication technologies into teacher education programs [Ogretim elemanlarinin bilgi ve iletisim teknolojilerini ogretmen egitim programlarina uyarlamasinda ilgi-endise ve benimseme seviyeleri]. Cukurova University Journal of Education [Cukurova Universitesi Egitim Fakultesi Dergisi], 37(3), 82-91.

Altun, T., (2012). Development of Information and Communications Technologies (ICT) Co-ordinators' Role Perceptions Scale (ICTCRPS). Elementary Education Online, 11(4), 869-881.

Aydin, H. (2000). Use of electronic performance support systems in teaches' trainin session. [Ogretmenlerin Hizmet Ici Egitiminde Elektronik Performans Destek Sisteminin Kullanilmasi]. Pamukkale University Journal of Education, 8(8), 141-150.

Baki, A. \& Ersoy, Y. (1998). Technology Preparation for In-service Mathematics Teachers Through a Short-Term Inservice Course, Proceedings of International Conference on the Teaching of Mathematics, John Wiley \& Sons, Inc. Publishers.

Belland, B. (2009). Using the theory of habitus to move beyond the study of barriers to technology integration. Computers \& Education, 52(2), 353-364.

Bingimlas, K. (2009). Barriers to the successful Integration of ICT in teaching and learning environments: A review of the literature. Eurasia Journal of Mathematics, Science \& Technology Education, 5(3), 235-245.

Borokhovski, E. F., Bernard, R. M., Tamim, R. M., \& Schmid, R. F. (2017). Technology integration in postsecondary education: a summary of findings from a set of related meta-analyses. Российский Психологический Журнал, 13(4), 284-302

Buyukozturk, S. (2007). Data analysis handbook for social studies [Sosyal Bilimler Icin Veri Analizi El Kitabi]. Ankara: Pegem A Publishing.

Capar, F., \& Vural, O. F. (2013). Obstacle to e-government: Digital division. [E-devletlesme onundeki engel: Dijital esitsizlik]. International Journal of Human Sciences, 10(1), 1674-1692.

Carlson, S. and C.T. Gadio. (2002). Teacher professional development in the use of technology. In W.D. Haddad and A. Draxler (Eds), Technologies for education: Potentials, parameters, and prospects. Paris and Washington, DC: UNESCO and the Academy for Educational Development. Retrieved 10 August 2011 from http://www.researchgate.net/profile/Gudmund_Hernes/publication/44828882_Emerging_trends_in _ICT_and_challenges_to_educational_planning/links/54415fee0cf2a76a3cc7e389.pdf\#page=124

Chen, F. Looi, C., \& Chen, W. (2009). Integrating technology in the classroom: A visual conceptualization of teachers' knowledge, goals and beliefs. Journal of Computer Assisted Learning, 25(5), 470-488.

Ciftci, S., Taskaya, S. M., \& Alemdar, M. (2013). The opinions of classroom teachers about Fatih Project.[Sinif ogretmenlerinin FATIH projesine iliskin gorusleri] Elementary Education Online, 12(1). 
Türel, Özdemir ve Varol - Çukurova Üniversitesi Eğitim Fakültesi Dergisi, 46(2), 2017, 503-516

Cudeck, R., \& O'Dell, L. L. (1994). Applications of standard error estimates in unrestricted factor analysis: Significance tests for factor loadings and correlations. Psychological Bulletin, 115, 475-487. doi:10.1037/0033-2909.115.3.475.1994-32085-00110.1037/0033-2909.115.3.475

Cure, F., \& Ozdener, N. (2008). Teachers' information and communication technologies (ICT) using achievements and attitudes towards ICT. [Ogretmenlerin bilgi ve iletisim teknolojileri (BIT) uygulama basarilari ve BIT'e yonelik tutumlari]. Hacettepe University Journal of Education, 34(34).

Davies, R. S., Dean, D. L., \& Ball, N. (2013). Flipping the classroom and instructional technology integration in a college-level information systems spreadsheet course. Educational Technology Research and Development, 61(4), 563-580.

Dawes, J. G. (2008). Do data characteristics change according to the number of scale points used? An experiment using 5 point, 7 point and 10 point scales. International journal of market research, 51(1).

Early Adopters of Technology (1999). Washington DC. Retrieved on December 21, 2012 from http://df/EDU0004.pdf++carly+adopters+of+technology+use \&hl=tr\&ie=utf-8

Ertmer, P. A. (1999). Addressing first- and second-order barriers to change: Strategies for technology integration. Educational Technology Research and Development, 47(4), 47-61.

Ertmer, P. A. (2005). Teacher pedagogical beliefs: The final frontier in our quest for technology integration?. Educational technology research and development, 53(4), 25-39.

Eryilmaz, S. (2014). An Inquisition upon Expectations of Intervening Teachers and Students within the Context of Fatih Project and Perceptions to Usage of Information Technology. Journal of Education and Practice, 5(12), 24-35

European Commission (2010). i2010 Benchmarking. http://ec.europa.eu/informationsociety/ eeurope/i2010/benchmarking/index_en.htm

Ezziane, Z. (2007). Information technology literacy: Implications on teaching and learning. Educational Technology \& Society,10(3), 175-191.

Fornell, C. \& Larcker, D. F. (1981). Evaluating structural equation models with unobservable variables and measurement error. Journal of Marketing Research, 18(1), 39-50.

Galanouli, D., Murphy, C., \& Gardner, J. (2004). Teachers' perceptions of the effectiveness of ICTcompetence training. Computers \& Education, 43(1-2), 63-79.

Gerbing, D. W. \& Anderson, J. C. (1988). An updated paradigm for scale development incorporating unidimensionality and its assessment. Journal of Marketing Research, 25(2), 186-192.

Gokdas, I. (2003). Effect of computer and classroom settings situated learning based on student success and transfer [Bilgisayar ve sinif ortamina dayali durumlu ogrenmenin ogrenci basarisi, tutum ve transfere etkisi.] Unpublished PhD Dissertation, Ankara University, Ankara.

Guven, I. (2001). International Aspects of teacher education [Ogretmen Yetistirmenin Uluslararasi Boyutu ](UNESCO 45. International Education Congress). Ministry of Education Journal (Milli Egitim Dergisi), 150 .

Hair, J. F. J., Anderson, R. E., Tatham, R. L., \& Black,W. C. (1995). Multivariate data analysis (4th ed.). Saddle River, NJ: Prentice Hall.

Hakkarainen, K., Homaki, L., Lipponen, L., Muukkonen, H., Rahikainen, M., Tuominen, T., Lakkala, M., Lehtinen, E., (2000). Students' skills and practices of using ICT: results of a national assessment in Finland. Computers \& Education, 34, 103-117.

Hawkridge, D. (1983). New Information Technology in Education. Londra: Croom Helm. 
Türel, Özdemir ve Varol - Çukurova Üniversitesi Eğitim Fakültesi Dergisi, 46(2), 2017, 503-516

Hayton, J. C., Allen, D. G., ve Scarpello, V. (2004). Factor retention decisions in exploratory factor analysis: A tutorial on parallel analysis. Organizational Research Methods, 7, 191-2005.

Henson, R. K., \& Roberts, J. K. (2006). Use of exploratory factor analysis in published research common errors and some comment on improved practice. Educational and Psychological measurement, 66(3), 393-416.

Hernández-Ramos, J. P., Martínez-Abad, F., Peñalvo, F. J. G., García, M. E. H., \& Rodríguez-Conde, M. J. (2014). Teachers' attitude regarding the use of ICT. A factor reliability and validity study. Computers in Human Behavior, 31, 509-516.

Horn, J. L. (1965). A rationale and test for the number of factors in factor analysis. Psychometrika, 30, 179-185.

ISTE, International Society for Technology in Education. (2008). National educational technology standards for teachers. Eugene: ISTE Publications.

Jenson, J., Lewis, B., \& Smith, R. (2002). No One Way: Working Models For Teacher Professional Development. Journal of Technology And Teacher Education. 10, 481-496.

Jhurree, V. (2005). Technology integration in education in developing countries: Guidelines to policy makers. International Education Journal, 6(4), 467-483.

Joliffe, I. T., \& Morgan, B. J. T. (1992). Principal component analysis and exploratory factor analysis. Statistical methods in medical research, 1(1), 69-95.

Jonassen, D. H., \& Reeves, T. C. (1996). Learning with technology: Using computers as cognitive tools. In D. H. Jonassen, (Ed.), Handbook of research on educational communications and technology (pp. 693-719). New York: Macmillan.

Kalayci, S., \& Humiston, K. R. (2015). Students' Attitudes Towards Collaborative Tools In A Virtual Learning Environment. Educational Process: International Journal, 4 (1-2), 71-86.

Kline, R. B. (2011). Principles and practice of structural equation modeling (3rd ed.). New York: The Guildford Press.

Kogce, D., Aydin, M., \& Yildiz, C. (2010). Freshman and senior pre-service mathematics teachers' attitudes toward teaching profession. The International Journal of Research in Teacher Education, $1(2), 2-18$

Korkmaz, O. \& Demir, B. (2012). The effect of MNE in-service education studies on teachers' attitude and self-effcient upon information and communication technologies [MEB Hizmetici Egitimlerinin Ogretmenlerin Bilgi Ve Iletisim Teknolojilerine Iliskin Tutumlarina ve Bilgisayar Oz-Yeterliklerine Etkisi]. Educational Technology Theory and Practice, 2(1).

Kutluca, T., Arslan, S. \& Ozpinar, I., (2010). Developing a Scale to Measure Information and Communication Technology Utilization Levels. Journal of Turkish Science Education, 7(4), 37-45

Lautenschlager, G. J. (1989). A comparison of alternatives to conducting Monte Carlo analyses for determining parallel analysis criteria. Multivariate Behavioral Research, 24, 365-395.

Manoucherhri, A. (1999). Computers and school mathematics reform: Implications for mathematics teacher education. Journal of Computers in Mathematics and Science Teaching, 18(1), 31-48.

MoNE (2006). Temel egitime destek projesi "ogretmen egitimi bileseni" ogretmenlik meslegi genel yeterlikleri, Journal of Announcements [Tebligler Dergisi], 2590, 1491-1540.

Moore, J., Knuth, R., Borse, J., \& Mitchell, M. (1999). Teacher Technology Competencies: Early Indicators and Benchmarks, Paper Presented Annual Conference of SITE'99 (Society for Information Technology 
Türel, Özdemir ve Varol - Çukurova Üniversitesi Eğitim Fakültesi Dergisi, 46(2), 2017, 503-516

\& Teacher Education), USA.

Oncu, S. Delialioglu, O. \& Brown, C.A. (2008). Critical components for technology integration: How do instructors make decisions? Journal of Computers in Mathematics and Science Teaching, 27(1), 1946.

Ping, R. A. (2009). "Is there any way to improve Average Variance Extracted (AVE) in a Latent Variable (LV) X (Revised)?" [on-line paper]. http://home.att.net/ rpingjr/ImprovAVE1.doc)

Selwyn, N. (2011). Education and technology: Key issues and debates. A\&C Black.

Sheingold, K. (1995). Computers-Mediated Communication and the Online Classroom in Distance Learning. Computers-Mediated Communication Magazine, 2(4).

Shieh, CJ., \& Demirkol, M. (2014). Evaluation of the Effectiveness of Social Networks and their Usage by High School Students. Educational Process: International Journal, 3 (1-2), 7-18.

Simsek, O., \& Yazar, T. (2016). Education technology standards self-efficacy (ETSSE) scale: A validity and reliability study. Eurasian Journal of Educational Research, 63, 311-334, http://dx.doi.org/ 10.14689/ejer.2016.63.18

Suhr, D. D. (2006). Exploratory or confirmatory factor analysis? (pp. 1-17). Cary: SAS Institute.

Tabachnick, B. G. \& Fidell, L. S. (2001). Using Multivariate Statistics (4th Ed.). Pearson Education. Inc:

Thompson, B. (2004). Exploratory and confirmatory factor analysis: Understanding concepts and applications. American Psychological Association, Washington, DC.

Tinio, V. (2003). ICT in Education. ICT for Development, United Nations Development Programme, New York.

Tsai, C.-C. \& Chai, C. S. (2012). The "third"-order barrier for technology integration instruction: Implications for teacher education. In C. P. Lim \& C. S. Chai (Eds), Building the ICT capacity of the next generation of teachers in Asia. Australasian Journal of Educational Technology, 28(6), 1057-1060. Retrieved on 02.26.2015 from http://www.ascilite.org.au/ajet/ajet28/tsai-cc.html.

van Prooijen, J. W., \& van der Kloot, W. A. (2001). Confirmatory analysis of exploratively obtained factor structures. Educational and Psychological Measurement, 61, 777-792

Wang, Q., \& Woo, H. L. (2007). Systematic planning for ICT integration in topic learning. Educational Technology \& Society, 10(1), 148-156.

Watson, D.M. (2001). Pedagogy before technology: Re-thinking the relationship between ICT and teaching. Education and Information Technologies, 6, 251-266.

de Winter, J. C., \& Dodou, D. (2010). Five-point Likert items: t test versus Mann-WhitneyWilcoxon. Practical Assessment, Research \& Evaluation,15(11), 1-12.

Yalin, H. I. (2001). Evaluation of professional development programs [Hizmetici Egitim Programlarinin Degerlendirilmesi]. Journal of Ministry Education [Milli Egitim Dergis]i, 150.

Yavuz, S. \& Coskun, A. S. (2008). Attitudes and perceptions of elementary teaching through the use of technology in education [Sinif ogretmenligi ogrencilerinin egitimde teknoloji kullanimina iliskin tutum ve dusunceleri]. Hacettepe University Journal of Education [Hacettepe Universitesi Egitim Fakultesi Dergisi], 34, 274-286.

Yildiz, H., Saritepeci, M., \& Seferoglu, S. S. (2013). A study on the contributions of the in-service training activities within the scope of FATIH project to teachers' professional growth in reference to ISTE teachers' standards [in FATIH Projesi Kapsaminda Duzenlenen Hizmet-Ici Egitim Etkinlikleri ve ISTE Ogretmen Standartlari 377 Turkish]. Hacettepe Universitesi Egitim Fakultesi Dergisi [Hacettepe University Journal of Education], Special issue (1), 375-392. 
Türel, Özdemir ve Varol - Çukurova Üniversitesi Eğitim Fakültesi Dergisi, 46(2), 2017, 503-516

Yilmaz, M. (2007). Instructional technology in training primary school teacher [Sinif ogretmeni yetistirmede teknoloji egitimi. Gazi University Journal of Education [Gazi Egitim Fakultesi Dergisi], 27(1). ISO 690

Yilmaz, G., Yilmaz, B., \& Turk, N. (2010). Over-graduate thesis physical education and sports teacher's self efficacy of their jobs (Nevsehir City Model) [Beden egitimi ve spor ogretmenlerinin mesleklerine iliskin oz-yeterlik duzeylerinin incelenmesi (Nevsehir Ili Ornegi)]. Selcuk Universitesi Journal of Physical Education and Sport Science, 12(2), 85-90.

Yorulmaz, Y. I., Altinkurt, Y., \& Yilmaz, K. (2015). The Relationship between Teachers' Occupational Professionalism and Organizational Alienation. Educational Process: International Journal, 4 (1-2), 31-44.

Yurdakul, I. K. (2011). Examining technopedagogical knowledge competencies of preservice teachers based on ICT usage [Ogretmen Adaylarinin Teknopedagojik Egitim Yeterliklerinin Bilgi ve lletisim Teknolojilerini Kullanimlari Acisindan Incelenmesi]. Hacettepe University Journal of Education [Hacettepe Universitesi Egitim Fakultesi Dergisi], 40, 397-408.

Yuzgec, A. (2003). Use of information technology classrooms and evaluation of their effects [Bilgi Teknolojisi Siniflarinin Kullanimi ve Etkilerinin Degerlendirilmesi], Unpublished Master's Thesis [Yayinlanmamis Yuksek Lisans Tezi], Ankara University, Ankara. 